\title{
Protection of Traditional Fishermen in The Granting of Fishery Licenses in Indonesia
}

\author{
Muhamad Azhar ${ }^{1,2}$, Suhartoyo Suhartoyo ${ }^{1}$, Lita Tyesta $\mathrm{ALW}^{1}$, Putut $_{\text {Suharso }}{ }^{3}$, Vivi Endar Herawati ${ }^{4}$
}

\begin{abstract}
${ }^{1}$ Faculty of Law, Diponegoro University, Prof. H. Soedarto SH street, Semarang 50275 Indonesia
${ }^{2}$ Center For Administrative Law Studies, Diponegoro University, Prof. H. Soedarto SH street, Semarang 50275 Indonesia

${ }^{3}$ Departement of Library Science, Diponegoro University, Prof. H. Soedarto SH street, Semarang 50275 Indonesia

${ }^{4}$ Department of Aquaculture, Faculty of Fisheries and Marine Science, Diponegoro University, Prof. H. Soedarto SH street, Semarang 50275, Indonesia
\end{abstract}

\begin{abstract}
The granting of fishing licenses for large vessels is very detrimental to the existence of small fishermen. Small fishermen or so-called traditional fishermen are powerless to face the dominance of fishing pens and licenses by large boats. This study aims to determine the rare step in providing protection to traditional Indonesian fishermen on the granting of fishing licenses for large companies in Indonesia. This research is an empirical juridical research using statutory uproach approach, conceptual aproach, and comparative approach. Then analyzed using synthesis analysis. The results show that traditional fishermen tend not to have adequate legal protection in terms of fishing in Indonesian waters. Traditional fishermen tend to be allowed to compete with large vessels that have licenses to catch fish in the Indonesian territory. The granting of fishing licenses is not accompanied by certain obligations associated with traditional fishermen protection. If observed, the permit should have a fishing license charging certain liability obligations for the permit holder.
\end{abstract}

\section{Introduction}

Keywords: Traditional Fishermen, Licenses, Fisheries. Indonesian Waters.

The country of Indonesia as an archipelago consisting of large and small islands separated by sea with geographical conditions has a total area of $7,827,087 \mathrm{~km}^{2}$ and is located in the equatorial emeralds that have abundant natural resources, especially in marine and coastal areas that reach $3 / 4$ Indonesian territory (5.8 million $\mathrm{km}^{2}$ ). Physically, the sum of the island's 17,504 islands is the largest in the world. Beach near the coast of $81,000 \mathrm{~km}$ is the second longest in the world after Canada. The 5.8 million $\mathrm{km} 2$ marine area comprises an Exclusive Economic Zone of 2.7 million $\mathrm{km}^{2}$, an archipelago of $2.8 \mathrm{~km}^{2}$, and a marine area of $0.3 \mathrm{~km}^{2}$ [1].

The Unitary State of the Republic of Indonesia (NKRI) is the largest archipelagic country in the world declared in 1957 in the Djuanda Declaration, then confirmed in Law No. 17/1985 on the International Law of the Sea Convention (Law No. 17/1985). There are about $60 \%$ of Indonesians living in coastal areas as wide as $50 \mathrm{~km}$ from the coastline. In the cities and districts of this region, $80 \%$ of Indonesian industries operate to utilize coastal resources and dispose of their waste into coastal areas [2]. Coastal resources are the world's richest tropical marine biodiversity center, where $30 \%$ of

\footnotetext{
Corresponding author: $\underline{\text { azharundip@gmail.com }}$
}

the world's mangrove forests exist in Indonesia; $30 \%$ of the world's coral reefs exist in Indonesia, $60 \%$ of protein consumption comes from fishery resources, $90 \%$ of fish come from coastal waters within 12 nautical miles of coastline [3]. The large potential of fisheries and marine, causing many Indonesian people who work as fishermen, including traditional fishermen.

Protecting traditional fishermen is a government duty of a country. The existence of traditional fishermen in the fishing industry should be granted access by the government of a country [4]. The task is carried out through adannya government policies in favor of traditional fishermen. One such policy is the government of a country issuing government instruments that protect traditional fishermen, either in the form of beschikkingen (decision), regelingen (regulation) or beleidsregel (rules of wisdom). One of the strategies to protect traditional fishermen is through licensing instruments issued by the government. The type of licensing in the field of fisheries issued by the government (Table 1).

Table 1. Type of Fishery Licenses in Indonesia 


\begin{tabular}{|l|l|l|l|}
\hline No & \multicolumn{1}{|c|}{ Jenis Izin Perikanan } & Code & Days \\
\hline 1 & $\begin{array}{l}\text { Letter of Implementation of Fish } \\
\text { auction (TPI) }\end{array}$ & 1.3 & 14 \\
\hline 2 & Business License (SIUP) & 1.4 & 14 \\
\hline 3 & Fishing Permit (SIPI) & 1.5 & 14 \\
\hline 4 & $\begin{array}{l}\text { Letter Fish Breeding (STPbI) in } \\
\text { the Sea and Public Waters For } \\
\text { Regency / City }\end{array}$ & 1.6 & 14 \\
\hline 5 & $\begin{array}{l}\text { Permit for Indonesian Fishing } \\
\text { Catchers and Transporters } \\
\text { (SIKPPII) }\end{array}$ & 1.7 & 14 \\
\hline 6 & $\begin{array}{l}\text { Permit for Indonesian Fishing } \\
\text { Cargo (SIKPII) }\end{array}$ & 1.8 & 14 \\
\hline
\end{tabular}

Based on the data, it can be seen that licensing instruments that can be used as a means of protection of traditional fishermen are presented as shown in the table. If viewed from the substance, licensing should be able to guarantee that traditional fishermen can keep doing activities, without any barrier from other legal subjects in the form of companies or individuals who get permits.

Companies or individuals who own or obtain licenses from governments tend to ignore the basic rights of traditional fishermen. If explored in depth, according to the experts that the permit (verguning), vmerupakan approval from the authorities/government based on legislation to under certain circumstances deviate from the provisions of the prohibition of legislation. So the permit in principle is as a dispensation or release / exemption from a prohibition [5]. The existence of various types of permits obtained by both entrepreneurs and/or individuals tends to harm traditional fishermen. the activities of traditional fishermen became limited and less freely moved to conduct fishing activities of fishery resources.

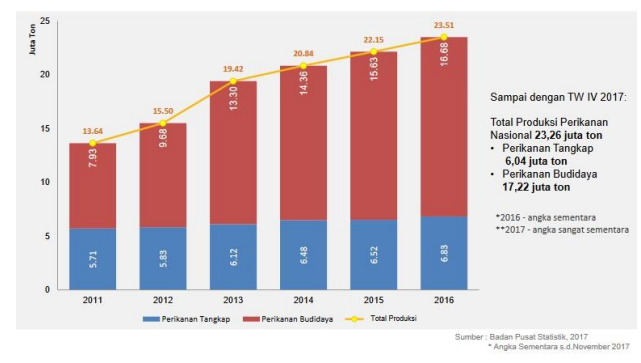

Fig. 1. Fisheries Production

According to research results from the Ministry of Marine Affairs and Fisheries, traditional fishermen tend to be less given access, not at all noticed. Traditional fishermen are not given access, and tend to be teared or underestimated. Although the number of tradional fishermen in Indonesia from year to year has decreased (see BPS data). Traditional fishermen experienced a decrease from the previous 1.6 million to 864 thousand people. In addition to the number of traditional fishermen declining, but the amount of income they jurxu increased. The quality of traditional fishermen's economic income also increased. In 2017, the government managed to lift the growth in the field of fisheries. As in the visible from Fig. 1. while the average exchange rate of traditional fishermen per year has increased as shown in Fig. 2.

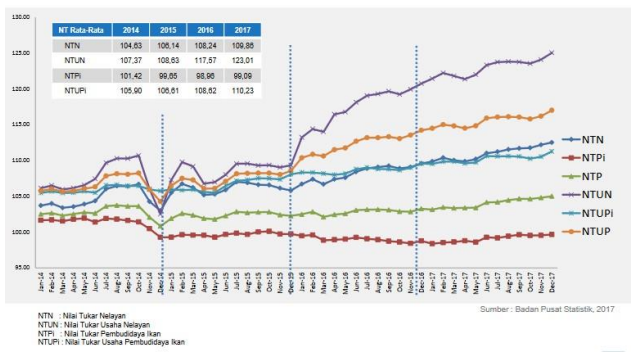

Fig. 2. The average exchange rate of traditional fishermen

Based on the problematic, then the question that will be answered in this article is as a model and strategy of traditional fishermen protection through the granting of fishery business permit in Indoenesia. The question is later described by writing method using empirical juridical research approach using statutory uproach approach, conceptual aproach, and comparative approach. Then analyzed using synthesis analysis.

\section{Research Methods}

This research is a legal research looking from the aspect of social (non-doctrinal) perspective. The approach used is socio legal but also statutory uproach approach, conceptual aproach, in this case, the law is seen as a space for the process of scientific study in order to seek truth.

Thus writing is not confined by a model of thought alone in looking at a problem to be discussed. The domain of socio-legal studies conceptualizes the law as a norm as well as behavior, the law is seen as merely as concrete, written, sanctioned and issued by authorized institutions which in its work are influenced by various other factors such as economics, politics, culture, religion, etc [6]. The use of relevant legal research would like to understand the law more thoroughly [7]. In this case, socio-legal research leads to a more thorough, whole, not textual understanding of law. Want to know whether the rule is effective, positive, productive, or even disturbing and destructive [8] [9].

\section{Result and discussion}

In this section of the results and discussion, it will explain three main points related to the protection of traditional fishermen, the justice factor in traditional enforcement, and the granting of fishery permits. The explanation is as follows: 


\subsection{Protection of traditional fishermen}

Based on the provisions of Law no. 45/2009 on Amendment to Law no. 31/2004 on Fisheries affirmed that the utilization of fishery resources should be done in an environmentally friendly manner and fishing gear. This assertiveness is intended as an effort to preserve not only the environment but also the sustainability of fish resources. In support of this policy, the government established a number of policies, among others, defining the type, quantity, and size of fishing gear; type, quantity, size, and placement of fishing aids, and the area, path, and time or season of fishing. This is done in order to maintain the existence of fishery resources remain sustainable and can be enjoyed by all people of Indonesia.

At this time, traditional fishermen are getting high attention from policy policies taken by the government. The policy is in favor or affirmative policy in order to improve the standard of living of traditional fishermen to continue or continue fishing activities [10]. This form of protection of traditional fishermen is poured in the form of easiness to obtain permits for the utilization of fishery resources. The government also encourages local governments to facilitate the existence of traditional fishermen through financial facilities and infrastructure facilities.

Presidential Instruction no. 15 of 2011 on the Protection of Fishermen which reinforces the role and function of all sectors, both government and local government, in protecting and empowering fishermen in Indonesia. Similarly, Law no. 31 of 2004 and its revision No. 45 Year 2009 on Fisheries that mandate to the government also to issue Government Regulation on Empowering Small Fishermen and Small-Scale Fish Cultivators.

In the Presidential Instruction, the President instructs each of the relevant ministers, Governors and Regents/ Mayors, to undertake the necessary steps in accordance with their respective duties, functions and authorities in a coordinated and integrated manner to provide welfare, assurance and protection law for fishermen [11] which operates fishing vessels up to 60 Gross Tonnage (GT). In carrying out these steps, each party coordinates related matters according to their respective fields.

Thus, it can be seen that the protection of traditional fishermen is a mandate of the laws and regulations in the field of fisheries. The mandate is contained in the basic principles of fisheries policy implementation. the necessity to see the sustainability factor of a fishery resource becomes one of the important points of consideration in policy making in the field of fisheries. the principle of sustainability in the utilization of fisheries is one strategy for traditional fishermen to survive and continue.

\subsection{Justice factor for fishermen}

Nationally, Indonesia has four homework, including homework as described below: First, the high poverty rate. Based on the causes of poverty, the poverty of coastal communities is divided into three types: (i) structural poverty, (ii) cultural poverty, and (iii) natural poverty. Secondly, access to the use of coastal and marine areas by traditional fishermen, and utilize the natural resources in it that are not impartial. Third, the ease of accessing the market for traditional fishermen is classified as an economic (socio-cultural) right expressed specifically in the constitution.

In this case the dependence on the market. At this point, the state must provide maximum service to traditional fishermen. This is because the commodities produced must be immediately sold to meet the needs of everyday life or decay before the sale. Fourth, access to management, where resources are not fully accessible due to the dominance of state law, is sometimes made not in a participatory way and is the result of consideration from the central government without regard to socioeconomic aspects of local communities. As a result, the policies issued precisely cause new problems because each party has interests, desires and priorities that exist is the source of triggering the emergence of conflict [12].

The existence of traditional fishermen who generally utilize fishery resources with simple patterns and usually with local coastal wisdom, also competed in the same region. This area should get special protection considering the status of small fishermen using simple fishing gear. In the Fisheries Act there are already several arrangements and on empowering small fishermen and small fish-breeders. This includes playing an important role by utilizing licensing instruments as one of the traditional means of protection of fishermen.

Another emphasis, for example by looking at a number of provisions: (1) Small fishermen are free to catch fish in all fisheries management areas of the Republic of Indonesia; (2) Small fish farmers can cultivate selected fish commodities throughout the fishery management area of the Republic of Indonesia; (3) Small fishermen and small fish farmers are obliged to comply with the conservation provisions. (4) Small fishermen or small fish farmers must participate in preserving the fishery environment and fishery product safety in accordance with applicable provisions [13]; (5) Small fishermen and small fish farmers should register themselves, businesses, and activities to local fisheries agencies, at no charge, for statistical purposes and for small-scale fishermen and fish-breeders.

Such a condition is very important, because it involves a sense of justice. In the context of social psychology, although what they receive is still quite far from the word fair [14]. The distribution of resources and benefits, to rights and remuneration, positions and convenience, which are fair will be judged satisfactory. Conversely, distributions that are considered unfair will cause dissatisfaction. Fair judgment will have an impact on positive social behavior, while an unfair judgment will have a negative impact. One of its forms is the relative deprivation often expressed in protest, anarchy, and rebellious behavior, or even the destruction of coral reefs. The principle of justice in the rule of law, seeks to derive a midpoint between two interests, on a single 
system of states to exercise power and on the other side society must be protected [15].

From the whole description, it can be seen that the justice factor as one of the drivers or triggers of traditional fishermen protection policy. the existence of traditional fishermen should be able to synergize with the policies issued by the government, so that national development can run as planned. Laying the interests of traditional fishermen on the other interests is one of the efforts to ensure identical poverty in the traditional fishing environment can be pressed.

\subsection{The granting of fishery permits}

The granting of fishery permits is entirely the authority of the government. However, in the use of such authority, it must always be based on the applicable laws and regulations as well as the general principle of governance [16]. If examined more deeply, the granting of permits must meet the minimum standard suatau permit issued, as the following provisions; 1) Authority: Any legal action by the government, principally within the State of the law, whether in the conduct of the regulatory or service functions, shall be based on the authority granted by applicable laws and regulations. So without clear authority that can never be made concrete decisions juridically. In this case, the granting of a fishery permit can only occur if true authority arises which attribution exists or is known to exist. 2) As a form of stipulation: In a modern State of law, the duties and authorities of the government are not merely to maintain order and order, but also to seek the common good (bestuurszorg). The duty and authority of the government to maintain order and security is a classic task that is still maintained today. It is within the framework of this task that the government is granted authority in the field of arrangement, which of this functioning of authority appears to some juridical instrument to face individual and concrete events, this provision is the spearhead of the legal instrument in the administration of government. 3) Government

Institutions: Institutions, theoretically is a rule of the game that knows can take action and determine whether an organization can run efficiently and effectively. Thus, institutional arrangements can be the enablers of success and also if not appropriate in the arrangement, it will be the Contraint of duties including the task of licensing of tea everything that requires the permission of the government/State. 4) Concrete events: It is said that permission is a juridical instrument in the form of statute, which is used by the government in the face of concrete and individual events. Concrete events mean that occurring at a certain time, certain people, certain places, and certain legal facts. Because these concrete events are diverse, permits also vary. Such diverse licenses are made in a process whose procedure depends on the authority of the licensor, the kinds of permits and organizational structure of the institution that issued it. 5) Processes and procedures: Licensing processes and procedures may include licensing service procedures, licensing completion processes which are the licensing completion process undertaken by officers / officers. In each stage of the job, each employee can know their respective roles in the licensing settlement process.

From the description, it can be understood that having policy instruments related to fishery permits, can be used as a means of prevention and control of environmental pollution. Instruments which are solely the authority of the ruler are classified into public legal instruments. Public legal instruments are distinguished in direct regulation and financial arrangements. Direct direct arrangement is done through commands (geboden) and prohibition of prohibition (verboden). The most direct regulatory form of prevention is prohibition (verboden) unless permission is given.

Fishery permit is one form of state administrative decision (beschikking). Decision is the right measuring instrument in relation to fishery management which must be accompanied by the requirements and consideration of fishery area as an effort to prevent the existence of violation in the field of fishery. The authority to regulate fisheries management is based on government authority. Such authority according to the verdict of the Constitutional Court of the Republic of Indonesia is translated as beheersdaad, Beleidsdaad, Berstuursdaad, Regelendsdaad, and toezichthoudensdaad.

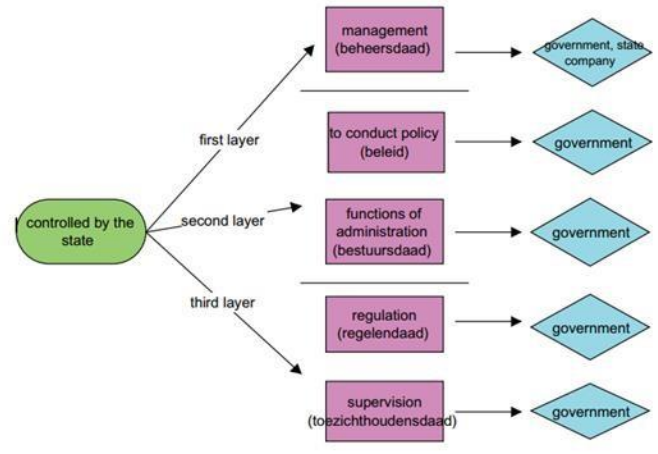

Fig. 3. Contitutional Court interpretation on Controlled by State

In Decision No 002/PUU-I/2003 on the judicial review of the Oil and Gas Law, the Constitutional Court stated that: 'controlled by the state' must be interpreted to include the meaning of a wide-ranging state occupation, as a result of the people's sovereignty concept over 'soil, water, and natural wealth contained therein', comprising also the meaning of public ownership over the aforementioned sources of wealth. The people, collectively constructed by the 1945 Constitution, provide a mandate to the state to conduct policy (beleid) and functions of administration (bestuursdaad), regulation (regelendaad), management (beheersdaad), and supervision (toezichthoudensdaad) for the welfare of the people to the utmost. From the Constitutional Court opinion (Fig. 1), it can be construed that the phrase 'controlled by state' can be interpreted widely, not only as ownership in the private law context 
but also in the context of public ownership. In the context of public ownership, the state has received a mandate from the people over fivem matters: to conduct policy (beleid) and functions of administration (bestuursdaad), regulation (regelendaad), management (beheersdaad) and supervision (toezichthoudensdaad).

Fisheries resources as well as other natural resources. Some of the special characteristics are: 1) Resources are generally invisible 2) Resources are common property 3 ) Exploitation of resources involves high risk 4) The product is very vulnerable (ie, highly perishable).

Furthermore, it can be said that the characteristics that cause more difficult process of utilization of fishery resources compared with other resources. Therefore, the tools of fisheries sciences are needed to enable the utilization of these resources, which include biological, technological, social and economic aspects. The understanding in the Regulation of the Minister of Marine and Fisheries of the Republic of Indonesia No.12 /MEN/2012 can be seen that fishing business is a fishery business based on fishing activities and / or fish transportation activities (Article 1 Paragraph 1). Fishery Company is understood as a company conducting fishery business and conducted by Indonesian citizen or Indonesian legal entity (Article 1, paragraph 3).

Fishing is an activity to obtain fish in waters that are not cultivated by any means or means, including activities that use vessels to load, transport, store, cool, handle, process and/or preserve it (Article 1, paragraph 6) vessels, boats or other floating apparatus used for fishing, supporting fishing operations, fish cultivation, fish transportation, fish processing, fishery exploration and fisheries research / exploration (Article 1, paragraph 8). Fishing vessels are ships specifically used for fishing, including storing, storing, cooling and / or preserving (Article 1, paragraph 9).

In conducting fishery activities, it must be equipped with a fishery business permit. SIUP is a written permit that must be owned by a fishery company to conduct a fishery business using production facilities listed in the license. in addition to the fishing business permit there is also a fishing permit, or known as SIPI is a written permission that must be owned by every fishing vessel to make fishing which is an integral part of SIUP. In addition to these two types, there is also a permit fish carrier ship, hereinafter abbreviated SIKPI. This permit is prestigious as a written permit that every fishing vessel must have to carry fish transportation which is an integral part of SIUP. The existence of permits should be utilized by the government as a means in order to protect traditional fishermen. For example by limiting the existence of permits granted to a legal entity or individual. In fact, various types of permits may be moratorium (suspension).

The regulation also regulates types of licensing concerning fisheries business which include: fishing business, fishery business license and SIPI (Fishing Permit), Fishing Business, SIUP (Fishery Business License) and SIKPI (Surat Izin Fish Fishing and Fishery Business License, Fishery Business License SIUP
(Fishery Business License) and Business Processing of SIUP (Fishery Business License). In the Fishing Permit License (SIPI) the main component of capture fisheries is the fishing unit, which consists of boats or ships, fishing gear and labor or fishermen that are interconnected and affect each other.

From the description it can be said that, the government should be able to make efforts in order to limit the existence of legal entities in possession of fishery permits. Such restrictions may be made as long as the objective is within the framework of the protection of traditional fishermen. not only limiting but also can be done penyetopan (moratorium) the existence of fishery permits in order to provide opportunities to traditional fishermen to gain access to existing fishery resources.

\section{Conclusion}

Based on the results of this study it can be concluded that as follows: Protection of traditional fishermen is a mandate of the laws and regulations in the field of fisheries. The mandate is contained in the basic principles of fisheries policy implementation. Justice factor as one of the triggers or trigger the existence of traditional fishermen protection policy. as well as government participation may limit the existence of legal entities related to fisheries. Such restrictions may be made as long as the objective is within the framework of the protection of traditional fishermen. Not only to limit but also to the moratorium on the existence of fishery permits to provide opportunities for traditional fishermen to gain access to existing fishery resources.

\section{References}

1 Ramlan, "Unlawful Acts of Foreign Investment in the Field of Fisheries in Indonesia (Perbuatan Melawan Hukum Penanaman Modal Asing Bidang Usaha Perikanan di Indonesia)," J. Yust., vol. 5, no. 1 (Januari-April), pp. 31-40, 2016.

2 D. Yono and I. Permadi, "Social Justice of Indigenous Peoples in Coastal Management (Keadilan Sosial Masyarakat Adat dalam Pengelolaan Wilayah Pesisir)," Semin. Nas. Huk., vol. 2, no. 1, pp. 299-322, 2016.

3 M. Azhar, "Prospect On Recognition Of The Traditional Fishing Rights In The Delimitation of Marine Waters Between Indonesia And The Philippines (Prospek Pengakuan Hak Perikanan Tradisional Dalam Penetapan Batas Perairan Wilayah Laut Antara Indonesia dan Filipina)," Yogyakarta: Postgraduate of Gadjah Mada University, 2011.

4 R. Kay and J. Alder, Coastal Planning and Management. London: Routledge, 1999. 
5 A. Sutedi, Law of Licensing in the Public Sector (Hukum Perizinan dalam Sektor Publik). Jakarta: Sinar Grafika, 2011.

6 F. A. Samekto, Law in the Development of Thought toward Post-Modernism (Ilmu Hukum dalam Perkembangan Pemikiran Menuju Post-

Modernisme). Lampung: Indep Publishing, 2012.

7 S. Halliday and P. Schmidt, Conducting Law and Society Research: Reflections on Methods and Practices. New York: Cambrige University Press, 2009.

8 S. Rahardjo, Building and Renovating Indonesian Law (Membangun dan Merombak Hukum Indonesia). Yogyakarta: Genta Publishing, 2009.

9 B. Z. Tamanaha, A General Jurisprudence of Law and Society. New York: Oxford University Press, 2006.

10 H. Y. Siry, "In search of appropriate approaches to coastal zone management in Indonesia," Ocean Coast. Manag., vol. 54, no. 6, pp. 469-477, 2011.

11 R. Dahuri and I. M. Dutton, "Integrated Coastal and Ocean Management Enters a New Era in Indonesia," 2000, p. 12, 2000.

12 A. Satria, Legal Assessment of the Protection of Traditional Fishermen in the Management of Marine Resources (Pengkajian Hukum Tentang Perlindungan Nelayan Tradisional dalam Pengelolaan Sumber Daya Kelautan). Jakarta: National Legal Development Board (Badan Pembinaan Hukum Nasional), 2012.

13 I. N. Putra A., A. Hakim, S. H. Pramono, and A. S. Leksono, "The effect of strategic environment change toward Indonesia maritime security: Threat and opportunity," Int. J. Appl. Eng. Res., vol. 12, no. 16, pp. 6037-6044, 2017.

14 A. M. Gai, I. Soewarni, and M. M. Sir, "The concept of community poverty reduction in coastal area of Surabaya based on sustainable livelihood approach," IOP Conf. Ser. Earth Environ. Sci., vol. 137, no. 12099, 2018.

15 Y. J. Utama, " Inauguration of Speech Professor of Law Sciences UNDIP: Building a State Administrative Courts of Authority (Pidato Pengukuhan Guru Besar Ilmu Hukum UNDIP: Membangun Peradilan Tata Usaha Negara Yang Berwibawa)," Diponegoro University, Semarang, 2010.

16 M. Azhar, "Relevance Good Governance Principles In State Administration Implementation System (Relevansi Asas-Asas Umum Pemerintahan Yang Baik Dalam Sistem Penyelenggaraan Administrasi Negara)," J. Notarius, vol. 9, no. 2, 2015. 